\title{
STUDI KOMPARASI AKTIVITAS ANTIOKSIDAN DAUN JERUK PURUT (Citrus hystrix DC) DAN DAUN JERUK NIPIS (Citrus aurantifolia (christm) Swingle) ASAL KOTA TERNATE MENGGUNAKAN METODE PEREDAMAN RADIKAL BEBAS DPPH
}

\author{
Virsa Handayani, Tadjuddin Naid, Ria Fitriani Umasangaji
}

Fakultas Farmasi Universitas Muslim Indonesia, Makassar Email: virsa.handayani@umi.ac.id

\begin{abstract}
Citrus (Citrus hystrix DC) and lime leaves (Citrus aurantifolia (christm) Swingle) are a Rutaceae family which contain flavonoids with antioxidant activity. The aim of this study is to compare the antioxidant activity of the citrus and lime leaves using DPPH free radical suppression method. The extraction of citrus and lime leaves by maceration method using ethanol $96 \%$. The antioxidant assay qualitatively by Thin Layer Chromatography (TLC) used the eluent $n$-hexane : ethyl acetat (7:3). The antioxidant assay quantitatively used DPPH free radical suppression method measured the absorption at the wavelength $515 \mathrm{~nm}$. The results showed that the $I C_{50}$ value of the citrus is $228.695 \mu \mathrm{g} / \mathrm{mL}$. This showed that the potential of the antioxidant activity of the sample is weak; however, the IC 50 value of the lime leaves is $335.064 \mu \mathrm{g} / \mathrm{mL}$. this showed that the antioxidant activity of thev sample is not active.
\end{abstract}

Key words : Antioxidant, citrus and lime leaves, DPPH.

\section{PENDAHULUAN}

Jeruk merupakan salah satu kekayaan flora yang dimiliki oleh Indonesia dan yang dapat dimanfaatkan sebagai tanaman pangan maupun obat. Jeruk berasal dari dataran Asia tepatnya dari dataran Cina. Jeruk telah lama dikenal dan dibudidayakan dan merupakan salah satu buah yang sangat digemari oleh masyarakat baik sebagai buah segar maupun olahan. Di Indonesia banyak terdapat varietas jeruk. Diantaranya jeruk nipis (Citrus aurantifolia (christm) Swingle) dan jeruk purut (Citrus hystrix DC).

Jeruk nipis (Citrus aurantifolia (christm) Swingle) dan jeruk purut (Citrus hystrix DC) merupakan jenis tanaman yang dapat digunakan sebagai obat tradisional. Bagian utama yang digunakan adalah buah, daun, dan kulit buah. Buah jeruk nipis (Citrus aurantifolia (christm) Swingle) dan jeruk purut (Citrus hystrix DC) digunakan untuk pengobatan influenza, penambah stamina. Sedangkan daun dan kulit buah dapat digunakan sebagai stimulan dan penyegar. ${ }^{3}$

Daun jeruk nipis mengandung flavonoid, seperti poncirin, hesperidin, rhoifolin. Daun jeruk nipis juga mengandung asam sitrat, asam amino (triptofan, lisin), minyak atsiri (sitral, limonene, felandren, tripenol, kamfen), dan vitamin $\mathrm{B}^{8}$, glikosida, tanin, dan pholobatannin. ${ }^{7}$ Daun jeruk purut mengandung flavonoid (sianidin, myricetin, peorridin, quercetin, luteolin, hesperetin, apigenin, dan isorhamnetin) dan aktivitas antioksidan, $\alpha$ tokoferol. ${ }^{2}$ Flavonoid sebagai salah satu kelompok senyawa fenolik yang banyak terdapat pada jaringan tanaman yang dapat berperan sebagai antioksidan. ${ }^{10}$ Antioksidan bermanfaat bagi kesehatan selain itu juga bermanfaat untuk produk pangan dalam menjaga mutu dari produk pangan tersebut. Antioksidan merupakan zat yang dapat menghambat dan mencegah terjadinya proses oksidasi atau menetralisir radikal bebas 
dengan cara bereaksi dengan radikal bebas reaktif membentuk radikal bebas tak reaktif yang stabil. ${ }^{13}$

Studi aktivitas antioksidan daun jeruk yang dilakukan Fidrianny et al menunjukkan aktivitas antioksidan daun jeruk nipis lebih tinggi dibandingkan daun jeruk purut, jeruk keprok, jeruk bali, dan jeruk lemon yang berasal dari Jawa Barat menggunakan metode DPPH dan FRAP. ${ }^{4}$

$$
\text { Hal diatas yang mendasari }
$$
dilakukannya penelitian dengan judul "Studi komparasi aktivitas antioksidan daun jeruk nipis (Citrus aurantifolia (christm) Swingle) dan daun jeruk purut (Citrus histryx DC) menggunakan metode DPPH".

\section{METODE PENELITIAN}

\section{Pengolahan sampel}

Sampel daun jeruk purut (Citrus hystrix DC) dan daun jeruk nipis (Citrus aurantifolia (christm) Swingle) yang diperoleh dari Kota Ternate dibersihkan dari kotoran yang melekat dengan menggunakan air mengalir kemudian dipotong-potong dan dikeringkan dengan cara diangin-anginkan. Setelah kering, sampel diserbukkan dan diekstraksi dengan cara maserasi. ${ }^{14}$

\section{Ekstraksi}

Serbuk daun jeruk purut (Citrus hystrix DC) dan jeruk nipis (Citrus aurantifolia (christm) Swingle) masing-masing ditimbang sebanyak $450 \mathrm{gr}$, kemudian dimasukkan sampel yang akan di sari kedalam bejana maserasi. Dituang secara perlahan etanol $96 \%$ sebanyak 1,5 L kedalam bejana maserasi yang berisi serbuk daun jeruk nipis (Citrus aurantifolia (christm) Swingle) dan daun jeruk purut (Citrus hystrix DC). Kemudian biarkan cairan penyari merendam serbuk simplisia selama 3 hari sesekali dilakukan pengadukan, dilakukan maserasi 3 kali dengan pelarut 1,5 L. Kemudian disaring kedalam wadah baru sehingga diperoleh ekstrak cair. Ekstrak cair diuapkan hingga diperoleh ekstrak kental. ${ }^{14}$

\section{Skrining Fitokimia Sampel}

Identifikasi alkaloid ${ }^{15}$

Ekstrak etanol daun jeruk purut (Citrus hystrix DC) dan jeruk nipis (Citrus aurantifolia (christm) Swingle) dimasukkan kedalam masing-masing tabung reaksi kemudian ditetesi :

1. $\mathrm{HCl} 0,5 \mathrm{~N}$ dan pereaksi Mayer, jika mengandung alkaloid maka akan menghasilkan endapan kuning.

2. $\mathrm{HCl} 0,5 \mathrm{~N}$ dan pereaksi Bauchardat, jika mengandung alkaloid maka akan menghasilkan endapan coklat.

3. $\mathrm{HCl} 0,5 \mathrm{~N}$ dan pereaksi Dragendrof, jingga mengandung alkaloid akan menghasilkan endapan jingga.

\section{Identifikasi flavonoid}

Sampel daun jeruk purut (Citrus hystrix DC) dan jeruk nipis (Citrus aurantifolia (christm) Swingle) diambil sebanyak $1 \mathrm{gr}$, masingmasing dimasukkan dalam labu erlenmeyer dan ditambah etanol $25 \mathrm{~mL}$. Kemudian dipanaskan sampai mendidih dan disaring. Filtrat yang diperoleh diuapkan sampai volume pelarut tinggal setengahnya. Filtrat dibagi menjadi dua, tabung pertama blanko dan tabung kedua ditambah beberapa tetes etanol, dikocok kemudian ditambahkan serbuk magnesium dan teteskan $5 \mathrm{M}$ asam klorida. Bila timbul warna merah maka ekstrak mengandung flavonoid.

\section{Identifikasi saponin ${ }^{11}$}

Sampel sebanyak $20 \mathrm{mg}$ dimasukkan ke dalam tabung reaksi, kemudian tambahkan aquades sampai seluruhnya terendam, kemudian panaskan selama 5 menit. 
Dinginkan, lalu kocok kuat-kuat sampai berbusa. Timbulnya busa yang stabil selama 510 menit menunjukkan adanya saponin.

\section{Identifikasi fenol ${ }^{15}$}

Ekstrak etanol cair diambil sebanyak 1 ml kemudian ditambahkan 2 tetes larutan $\mathrm{FeCl}_{3}$ $5 \%$. Terbentuknya warna hijau atau hijau biru menunjukkan adanya senyawa fenol dalam sampel.

\section{Uji Aktivitas Antioksidan Ekstrak Etanol}

\section{Sampel Secara Kualitatif}

Ekstrak etanol daun jeruk purut (Citrus hystrix DC) dan jeruk nipis (Citrus aurantifolia (christm) Swingle) masing-masing dilarutkan dengan aseton dan ditotolkan pada lempeng KLT kemudian dielusi dengan menggunakan eluen $n$-Heksan : Etil asetat (7:3). Ekstrak yang sudah ditotol pada lempeng KLT dielusi dan diamati di bawah sinar UV $254 \mathrm{~nm}$ dan $366 \mathrm{~nm}$. Lempeng KLT disemprot dengan menggunakan 1,1-Diphenyl-2-Picryl Hydrazil (DPPH) dan dibiarkan mengering dan diamati terdapat noda berwarna kuning pada lempeng. ${ }^{5}$

Uji Aktivitas Antioksidan Ekstrak Etanol Sampel Secara Kuantitatif

Uji aktivitas antioksidan dari ekstrak etanol daun jeruk purut (Citrus hystrix DC) dan jeruk nipis (Citrus aurantifolia (christm) Swingle) diuji degan menggunakan metode peredaman radikal bebas DPPH.

\section{Pembuatan larutan stok DPPH}

Serbuk DPPH sebanyak 2,5 mg dilarutkan dengan $100 \mathrm{~mL}$ pelarut metanol p.a didalam labu tentukur untuk memperoleh larutan stok dengan konsentrasi 25 ppm.

\section{Penentuan panjang gelombang maksimal larutan DPPH.}

Larutan stok DPPH 25 ppm dipipet 4 $\mathrm{mL}$ lalu diinkubasi pada suhu $37^{\circ} \mathrm{C}$ selama 30 menit. Kemudian diukur absorbansinya pada panjang gelombang maksimal.

Pengukuran daya antioksidan ekstrak sampel.

Ekstrak etanol daun jeruk purut (Citrus hystrix DC) dan jeruk nipis (Citrus aurantifolia (christm) Swingle) ditimbang sebanyak $10 \mathrm{mg}$ dan dilarutkan dengan metanol p.a sambil diaduk dan dihomogenkan lalu cukupkan volumenya hingga $10 \mathrm{~mL}$. Selanjutnya dilakukan pengenceran pada sampel daun jeruk purut (Citrus hystrix DC) dengan seri konsentrasi 50 ppm, 100 ppm, 120 ppm, 130 ppm, dan 140 ppm dimana masing-masing dipipet $0,25 \mathrm{~mL}, 0,5 \mathrm{~mL}, 0,6 \mathrm{~mL}, 0,65 \mathrm{~mL}$ dan $0,7 \mathrm{~mL}$ kemudian dicukupkan dengan metanol p.a sampai volume akhir $5 \mathrm{~mL}$. dan dilakukan seri pengenceran pada sampel daun jeruk nipis (Citrus aurantifolia (christm) Swingle) dengan seri konsentrasi 60 ppm, 80 ppm, 100 ppm, 120 ppm, dan 140 ppm dimana masing-masing dipipet $0,3 \mathrm{~mL}, 0,4 \mathrm{~mL}, 0,5 \mathrm{~mL}, 0,6 \mathrm{~mL}$ dan 0,7 $\mathrm{mL}$ kemudian dicukupkan dengan metanol p.a sampai volume akhir $5 \mathrm{~mL}$. Seri konsentrasi yang telah dibuat masing-masing dipipet 0,5 $\mathrm{mL}$, lalu ditambahkan 3,5 mL larutan DPPH 25 ppm. Larutan campuran tersebut diinkubasi selama 30 menit pada ruang gelap. Kemudian diukur serapannya pada panjang gelombang $515 \mathrm{~nm}$.

\section{Pengukuran daya antioksidan sampel pembanding kuersetin}

Kuersetin ditimbang sebanyak $10 \mathrm{mg}$ dan dilarutkan dengan metanol p.a sambil diaduk dan dihomogenkan lalu cukupkan volumenya hingga $10 \mathrm{~mL}$, kemudian dilakukan pengenceran dengan seri konsentrasi 2 ppm, 4 ppm, 6 ppm, 8 ppm, 10 ppm, kemudian dicukupkan dengan metanol p.a sampai volume akhir $5 \mathrm{~mL}$. Seri konsentrasi yang telah 
Studi Komparasi Aktivitas Antioksidan Daun Jeruk Purut dan Daun Jeruk Nipis Asal Kota Ternate Menggunakan Metode Peredaman Radikal Bebas DPPH

dibuat masing-masing dipipet $0,5 \mathrm{~mL}$, lalu ditambahkan 3,5 mL larutan DPPH 25 ppm. Larutan campuran tersebut diinkubasi selama 30 menit pada ruang gelap. Kemudian diukur serapannya pada panjang gelombang $515 \mathrm{~nm}$.

\section{HASIL DAN PEMBAHASAN}

Radikal bebas adalah suatu molekul yang relatif tidak stabil dengan atom yang pada orbit terluarnya memiliki satu atau lebih elektron yang tidak berpasangan. Radikal bebas merupakan molekul kimia yang sangat reaktif dan disebut-sebut sebagai penyebab dari penuaan dini, kanker, penyempitan pembuluh darah (aterosklerosis), penyakit gangguan paru, hati, ginjal, katarak,rematik dan diabetes sering dikaitkan dengan radikal bebas. ${ }^{7}$

Antioksidan dapat melindungi sel-sel dari kerusakan yang disebabkan oleh molekul tidak stabil yang dikenal sebagai radikal bebas. Antioksidan adalah zat yang dapat menunda, memperlambat dan mencegah terjadinya proses oksidasi atau menetralisir radikal bebas. ${ }^{13}$

Penelitian ini menggunakan daun jeruk purut (Citrus hystrix DC) dan jeruk nipis (Citrus aurantifolia (christm) Swingle) yang diekstraksi dengan metode meserasi yang merupakan salah satu metode ekstraksi secara dingin. Metode ekstraksi yang digunakan adalah maserasi karena metode ini merupakan metode ekstraksi dengan cara dingin sehingga dapat menghindari rusaknya senyawasenyawa yang termolabil. ${ }^{16}$

Sampel daun jeruk purut (Citrus hystrix DC) dan daun jeruk nipis (Citrus aurantifolia (christm) Swingle) yang akan diekstraksi ditimbang sebanyak $450 \mathrm{~g}$ kemudian diekstraksi menggunakan pelarut etanol $96 \%$ sebanyak 1,5 L. Penggunaan pelarut etanol dalam proses ekstraksi dikarenakan lebih aman dalam penanganan dibandingkan pelarut organik lainnya seperti metanol dan aseton. Pelarut etanol memiliki aktivitas yang tinggi untuk menarik senyawa, bergantung pada konsetrasi pelarut etanol sendiri. ${ }^{1}$

Hasil ekstrak etanol kental yang diperoleh pada daun jeruk purut (Citrus hystrix DC) daun jeruk nipis (Citrus aurantifolia (christm) Swingle) seperti pada tabel 1.

Hasil dilakukan uji skrining dengan metode tabung pada sampel daun jeruk purut (Citrus hystrix DC) dan daun jeruk nipis (Citrus aurantifolia (christm) Swingle), kedua sampel mengandung fenol, flavonoid, dan saponin dan pada sampel tidak mengandung alkaloid seperti pada Tabel 2.

Tabel 1. Data persen (\%) rendamen sampel

\begin{tabular}{cccc}
\hline Sampel & Berat sampel segar $(\mathbf{g})$ & Berat ekstrak $(\mathbf{g})$ & Rendamen ekstrak (\%) b/b \\
\hline Daun jeruk purut & $450 \mathrm{~g}$ & 50,9073 & 11,313 \\
Daun jeruk nipis & $450 \mathrm{~g}$ & 44,5056 & 9,908 \\
\hline
\end{tabular}

Pengujian aktivitas antioksidan secara kualitatif dilakukan dengan menggunakan lempeng KLT. Ekstrak etanol daun jeruk purut (Citrus hystrix DC) dan daun jeruk nipis (Citrus aurantifolia (christm) Swingle) ditotolkan pada lempeng KLT kemudian dielusi dengan eluen $n$ -
Heksan : etil asetat (7:3). Setelah lempeng KLT dielusi kemudian disemprot dengan DPPH. Bercak noda yang memberikan perubahan warna menjadi kuning setelah disemprotkan dengan DPPH menunjukkan adanya aktivitas antioksidan ${ }^{5}$. 
Studi Komparasi Aktivitas Antioksidan Daun Jeruk Purut dan Daun Jeruk Nipis Asal Kota Ternate Menggunakan Metode Peredaman Radikal Bebas DPPH

Tabel 2. Data hasil skrining fitokimia ekstak etanol daun jeruk purut (Citrus hystrix DC) dan daun jeruk nipis (Citrus aurantifolia (christm) Swingle)

\begin{tabular}{lcc}
\hline \multicolumn{1}{c}{ Sampel } & Identifikasi & Hasil pengamatan \\
\hline Ekstrak etanol daun jeruk purut & Fenol & + \\
(Citrus hystrix DC) dan daun jeruk & Flavonoid & + \\
nipis (Citrus aurantifolia (christm) & Saponin & + \\
Swingle) & Alkaloid & - \\
\hline
\end{tabular}

Keterangan : $(+)=$ positif; $(-)=$ negatif.

Uji aktivitas antioksidan secara kualitatif pada sampel daun jeruk purut (Citrus hystrix DC) dan daun jeruk nipis (Citrus aurantifolia (christm) Swingle) menunjukkan adanya aktivitas antioksidan terdapat bercak kuning latar ungu pada lempeng KLT yang telah di semprotkan menggunakan DPPH.

Pengujian aktivitas antioksidan secara kuantitatif dilakukan menggunakan metode peredaman radikal bebas DPPH. Metode 1,1diphenyl-2-picrylhydrazil (DPPH) adalah metode yang paling sering digunakan untuk skrining aktivitas antioksidan dari berbagai tanaman obat. Prosedur ini melibatkan pengukuran penurunan serapan DPPH pada panjang gelombang maksimalnya, yang sebanding terhadap konsentrasi penghambat radikal bebas yang ditambahkan ke larutan reagen DPPH. Pengujian antioksidan dengan DPPH akan menghasilkan nilai $\mathrm{IC}_{50}$ (Inhibitor concentration) yang menyatakan seberapa besar konsentrasi ekstrak yang dibutuhkan untuk mereduksi radikal bebas (DPPH) sebanyak $50 \% .^{12}$

Sampel daun jeruk purut (Citrus hystrix DC) dan daun jeruk nipis (Citrus aurantifolia (christm) Swingle) yang akan diuji dibuat dalam konsentrasi 1000 ppm. Selanjutnya dilakukan pengenceran pada sampel daun jeruk purut (Citrus hystrix DC) dengan seri konsentrasi 50 ppm, 100 ppm, 120 ppm, 130 ppm dan 140 ppm sedangkan pada sampel daun jeruk nipis
(Citrus aurantifolia (christm) Swingle) dilakukan pengenceran dengan seri konsentrasi $60 \mathrm{ppm}$, 80 ppm, 100 ppm, 120 ppm, 140 ppm. Pada pengujian ini digunakan pembanding kuersetin. Kuersetin dibuat dalam konsentrasi 1000 ppm selanjutnya dibuat pengenceran dengan seri konsentasi 2 ppm, 4 ppm, 6 ppm, 8 ppm dan 10 ppm. Lalu dilakukan pengukuran menggunakan spektrofotometer UV-Vis. Selanjutnya dilakukan perhitungan persen inhibisi (\% inhibisi) dan nilai $\mathrm{IC}_{50}$ (inhibition concentration) dari masing-masing sampel dan pembanding.

Hasil yang diperoleh pada pengukuran pembanding, nilai $\mathrm{IC}_{50}$ kuersetin yaitu 5,087 $\mu \mathrm{g} / \mathrm{mL}$ ini menunjukkan kuersetin memiliki aktivitas antioksidan sangat kuat. Sedangkan pada sampel ekstrak etanol daun jeruk purut (Citrus hystrix DC) memiliki nilai $\mathrm{IC}_{50} 228,695$ $\mu \mathrm{g} / \mathrm{mL}$, ini menunjukkan sampel daun jeruk purut (Citrus hystrix DC) memiliki aktivitas antioksidan lemah dan pada sampel ekstrak etanol daun jeruk nipis (Citrus aurantifolia (christm) Swingle) memiliki nilai $I_{50} 335,064$ $\mu \mathrm{g} / \mathrm{mL}$, ini menunjukkan pada sampel daun jeruk nipis (Citrus aurantifolia (christm) Swingle).

Dari data diatas menunjukkan bahwa sampel ekstrak daun jeruk purut (Citrus hystrix DC) memiliki aktivitas antioksidan yang lemah dan daun jeruk nipis (Citrus arantifolia (christm) Swingle) tidak memiliki aktivitas antioksidan 
Adapun faktor kesalahan yang mungkin terjadi pada saat pengambilan sampel dan pengolahan. Kemungkinan faktor kerugian metode maserasi juga dapat menyebabkan beberapa senyawa hilang pada saat proses ekstraksi. ${ }^{16}$

Hal lain yang mungkin terjadi yaitu akibat pengeringan. Pengeringan bahan pangan seringkali dilakukan agar suatu bahan dapat disimpan lebih lama, namun proses pengeringan dapat menyebabkan kerusakan senyawa-senyawa di dalamnya, termasuk senyawa antioksidan alami. Beberapa penelitian pada tumbuhan mengenai aktivitas antioksidan dengan membandingkan sampel yang masih segar dan sampel yang telah dikeringkan, menunjukkan aktivitas antioksidan sampel yang masih segar lebih baik dibandingkan sampel yang telah dikeringkan.

\section{KESIMPULAN}

Daun jeruk purut (Citrus hystrix DC) memiliki aktivitas antioksidan dan daun jeruk nipis (Citrus aurantifolia (christm) Swingle) tidak memiliki aktivitas antioksidan. Ada perbedaan aktivitas antioksidan daun jeruk purut (Citrus hystrix DC) dan daun jeruk nipis (Citrus aurantifolia (christm) Swingle), dimana aktivitas antioksidan daun jeruk purut (Citrus hystrix DC) lebih tinggi dengan nilai $\mathrm{IC}_{50}$ 228,695 $\mu \mathrm{g} / \mathrm{mL}$ dibandingkan daun jeruk nipis (Citrus aurantifolia (christm) Swingle) yang tidak memiliki aktivitas antioksidan dengan nilai $\mathrm{IC}_{50} 335,064 \mu \mathrm{g} / \mathrm{mL}$.

\section{DAFTAR PUSTAKA}

1. Chew KK, Khoo MZ, Ng SY, Thoo YY, Wan Aida WM and Ho CW. Effect of ethanol concentration, extraction time and extraction temperature on the recovery of phenolic compounds and antioxidant capacity of Orthosiphon stamineus extracts. Int. Food Res Journal. 2011;18(4):1235-1427.
2. Ching LS and Mohamed S. Alphatocopherol content in 62 edible tropical plants. Journal of Agricultural and food Chemistry. 2001;49(6):31013105.

3. Dalimartha S. Atlas tumbuhan obat Indonesia, vol. 2. Jakarta : Niaga Swadaya, 2008.

4. Fidrianny I, Amaliah A and Sukrasno. Antioxidant Activities Evaluation of Citrus Leaves Extracts from West Java-Indonesia Using DPPH and Frap Assays. International Journal of Pharmacognosy and Phytochemical Research. 2016;8(4):611-618.

5. Handayani V, Ahmad AR and Sudir M. Uji Aktivitas Antioksidan Ekstrak Metanol Bunga dan Daun Patikala (Etlingera elatior (Jack) RM Sm) Menggunakan Metode DPPH. Pharm Sci and Res. 2016;1(2):8693.

6. Inggrid $M$ and Santoso $H$. Aktivitas Antioksidan Dan Senyawa Bioaktif Dalam Buah Stroberi, Research ReportEngineering Science. 2015;2.

7. Khaira K. Menangkal Radikal Bebas Dengan Anti-Oksidan. Jurnal Sainstek. 2010;2(2):183-187.

8. Latief A. Obat Tradisional. Jakarta : EGC, 2012.

9. Nweke FU. Effect of Citrus aurantifolia Leaf Extract on Mycelial Growth and Spore Germination of Different Plant Pathogenic Fungi. Advances in Life Science and Technology Journal. 2015;31:4-9.

10. Redha A. Flavonoid: struktur, sifat antioksidatif dan peranannya dalam sistem biologis (Skripsi). Pontianak : Jurusan Teknologi Pertanian Politeknik Negeri Pontianak, 2013.

11. Runtuwene MRJ dan Paendong J. Kajian Fitokimia dan Toksisitas Ekstrak Metanol Daun Pinang Yaki Areca Vestiaria Giseke. Chem. Prog.2011;4(2):80-84.

12. Salamah N, dan Widyasari E. Aktivitas Antioksidan Ekstrak Metanol Daun Kelengkeng (Euphoria longan (L) Steud.) Dengan Metode Penangkapan Radikal 2,2'-Difenil-1-Pikrilhidrazil. Pharmaçiana. 2015;5(1):25-34. 
13. Sembiring E, Sangi MS, dan Suryanto E. Aktivitas antioksidan ekstrak dan fraksi dari biji jagung (Zea mays L.). Chem. Prog.2016;9(1):14-20.

14. Suradji SI, Najib A, dan Ahmad AR. Studi Komparasi kadar flavonoid total pada bunga rosella merah (Hibiscus sabdariffa L.) asal Kabupaten Luwu Utara Provinsi Sulawesi Selatan dan Kabupaten Kediri Provinsi Jawa Timur. Jurnal Fitofarmaka Indonesia. 2016;3(2):175-181.
15. Syarif RA, Muhajir, Ahmad AR, dan Malik A. Identifikasi golongan senyawa antioksidan dengan menggunakan metode peredaman radikal DPPH ekstrak etanol daun Cordia myxa L. Jurnal Fitofarmaka Indonesia. 2015;2(1):83-89.

16. Tetti M. Ekstraksi, Pemisahan Senyawa, Dan Identifikasi Senyawa Aktif. Jurnal Kesehatan. 2014; 7(2):361-367. 